\title{
EEE
}

Homepage: http://publisher.uthm.edu.my/proceeding/index.php/eeee e-ISSN : 2756-8458

\section{Development of Solar-Powered Automatic Fertilizer System in Chili Fertigation Technology}

\author{
Nur Arni Munirah Shamsuddin ${ }^{1}$, Mohd Noor Abdullah ${ }^{2 *}$ \\ ${ }^{1}$ Department of Electrical Engineering, \\ Faculty of Electrical and Electronics Engineering, \\ Universiti Tun Hussein Onn Malaysia, Batu Pahat, 86400, MALAYSIA \\ ${ }^{2}$ Green and Sustainable Energy Focus Group (GSEnergy), \\ Faculty of Electrical and Electronics Engineering, \\ Universiti Tun Hussein Onn Malaysia, Batu Pahat, 86400, MALAYSIA
}

DOI: https://doi.org/10.30880/eeee.2020.01.01.005

Received 12 August 2020; Accepted 06 September 2020; Available online 30 October 2020

\begin{abstract}
This paper elucidates the concept of a solar-powered automatic fertilizer system, where the farmers are able to control the injection of fertilizer intake with the intention of tackling the overdose fertilizer intake and electricity accessibility issues. The main objectives of this paper are to design a photovoltaic (PV) system for automatic fertilizer system by considering the total of 300 chili crops, to develop an algorithm that can automatically agitate a proper proportion of fertilizer and to design a prototype for the development of the solar-powered automatic fertilizer system in chili fertigation technology. Arduino UNO is selected as the microcontroller to program the system while sensors such as EC sensor, ultrasonic sensor and flow rate sensor are used to initiate the agitation of fertilizer A, fertilizer B and water into the mixer tank. The system has been built accordingly and the performance of the system is tested. As a consequence, the result shows that the system is able to run with the aid of solar energy and the overall concept of the system can be implemented for the real application of the fertigation system.
\end{abstract}

Keywords: Automatic Fertilizer System, Arduino UNO, EC Feedback Mechanism, Fertigation Technology, PV Sizing, Renewable Resources, Solar Energy

\section{Introduction}

The contribution of $8.2 \%$ of Gross Domestic Product (GDP) in agriculture during 2017 has made agricultural sector as one of the important industries in Malaysia [1]. Modern agriculture such as the fertigation system can give a positive impact on the production of yield, apart from enhancing the income for entrepreneurs [2], [3]. Smart and intelligent system of irrigation and fertilization are the main key of modern farming in order to control the correct nutrient intake to the plants [4]. In conjunction with this, farmers should take this golden opportunity to broaden fertigation technology into the international market level. 
Upgradation of the fertilizer system can be one of the factors to commercialize the fertigation system in the agriculture industry. An effective fertilizer management system will improve the productivity of the plant as it provides a precise dosage of fertilizer, thus reducing the percentage of a wilted and dead plant due to excessive fertilizer intake [3], [5]. Production cost can also be reduced to a remarkable degree when applying the correct concept of fertilization [6]. This is because the price of commonly used fertilizer A and fertilizer B is quite high due to the contained ingredients that lie in these fertilizers. In fact, the prosecution of an automatic fertilizer system will bring lots of benefits when it comes to the cost, productivity, labor, human health and ecosystem [7]. With all of these advantages, the application of smart and intelligent solar-powered automatic fertilizer systems can be considered as a great solution to improve the weightage of GDP in the agricultural sector.

Statistically, Malaysia has produced solar irradiation around 400 to $600 \mathrm{MJ} / \mathrm{m} 2$ monthly [8]. The high production of solar irradiation can be advantageous to the farmers to implement the fertigation system with solar energy. Furthermore, the government lately has announced the new national renewable energy (RE) target, which is to attain $20 \%$ of RE penetration by the year 2025. From this policy, about $50 \%$ of the goal will come from solar technology whereas the remaining $50 \%$ will be coming from non-solar technology [9]. This target can probably be achieved by applying the solarbased system into various technology such as the fertigation system.

By considering the stated statement, this paper applied a solar-powered automatic fertilizer system in chili fertigation technology. Solar-powered automated fertilizer system deals with the photovoltaic $(\mathrm{PV})$ system that can control the injection of fertilizer A, fertilizer B, and water into the mixer tank with the ratio control based system. To supply an adequate concentration of fertilizer, ratio of fertilizer A: fertilizer B: water is being introduced. The electrical conductivity (EC) sensor is placed inside the mixer tank and the value of EC is then being displayed at the OLED display. A proper algorithm is implemented by using the Arduino UNO microcontroller in order to control the fertilizer intake specifically in chili fertigation technology.

\section{Methodology}

The method for designing PV system for 300 chili crops is further discussed in subtopic 2.1 whilst subtopic 2.2 consists of the overall block diagram of solar-powered automatic fertilizer system along with its flowchart for fertilizer mixing process.

\subsection{Designation of PV sizing for solar PV system}

Sizing is an essential part in the designation of the PV system. Consumer needs to consider several factors in order to obtain an optimal selection of solar cell panel, battery bank, and charge controller. Failure to do so will result in an undersized or oversized PV system that can negatively affect the further utilization of solar cells, apart from being an economic waste. Figure 1 shows the correct procedures when dealing with solar PV system sizing [10]. A further explanation for each PV sizing step is discussed in the next subtopic.

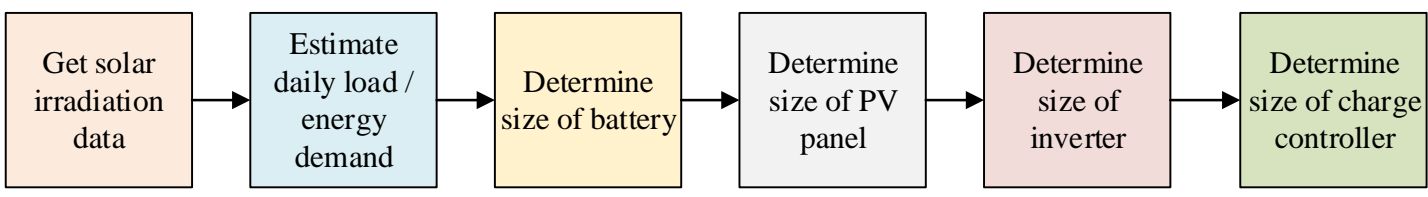

Figure 1: Stand-alone solar PV system sizing

\subsubsection{Solar irradiation data}

According to [8], Malaysia has produced a great amount of solar radiation throughout the year as compared to global standards. There is a fluctuation of global irradiation from 2 to $6 \mathrm{kWh} / \mathrm{m}^{2} /$ day, with an average temperature of $33^{\circ} \mathrm{C}$ during daytime and $23^{\circ} \mathrm{C}$ at night. Figure 2 summarizes solar radiation produced by different towns in Malaysia [11]. 


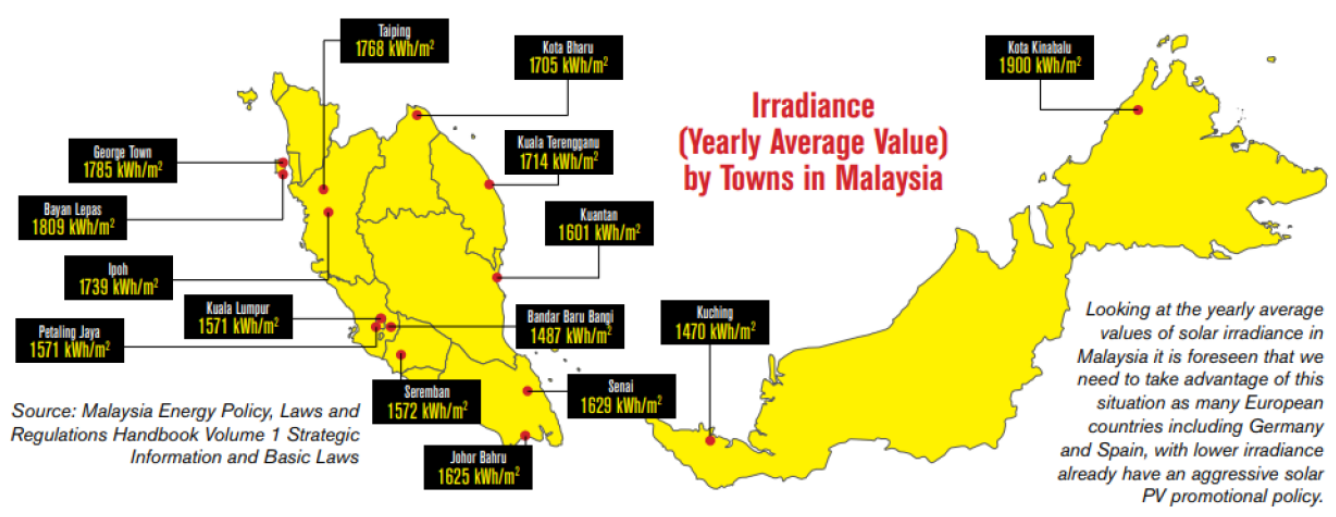

Figure 2: Solar irradiation in Malaysia

\subsubsection{Daily load estimation (energy demands)}

Load estimation is done by listing out all the loads and calculate the average daily usage for the system. In this project, the main load are the water pump and motor mixer. Therefore, before starting to estimate the energy demands that the loads have produced, the time taken for the motor pump to fill in the tank should be calculated by considering the flow-rate of the motor. Formula to calculate energy demands per day is shown in Eq. 1 [10].

$$
\begin{gathered}
E_{\text {load }_{i}}=(N \times P \times h) \\
E_{t}=\sum_{i=1}^{n} E_{\text {load }_{i}} \quad \text { Eq. } 1
\end{gathered}
$$

where $E_{\text {load }}$ is energy demands of the estimated $i^{\text {th }}$ loads in $W h, N$ is quantity of $i^{\text {th }}$ loads, $P$ is the power rating of $i^{\text {th }}$ loads and $h$ is the usage hours per day of the $i^{\text {th }}$ loads. $E_{t}$ is the algebraic sum of energy demands, $E_{\text {load }_{i}}$ in $W h$ while $i$ is the lower bounds of summation and $n$ is the upper bounds of summation.

\subsubsection{Battery bank sizing}

Lead-acid batteries are the normally used battery bank in the stand-alone PV system. This is due to its lower price even though this type of battery has low storage density and higher-self discharge. To calculate the battery capacity of the battery, some elements need to be put into attention such as battery efficiency, depth of discharge, the nominal voltage of the battery and so on. Eq. 2 summarizes the calculation for battery capacity $\left(B_{\text {cap }}\right)[12]$.

$$
B_{\text {cap }}=\frac{E_{t} \times A D}{V_{d c} \times D O D \times \eta} \quad \text { Eq. } 2
$$

where is the battery capacity in $A h, A D$ is the autonomous day, $V_{d c}$ is the nominal voltage of battery bank, $D O D$ is the allowable battery depth of discharge and $\eta$ is the total efficiency of cable, battery, charge controller and inverter.

\subsubsection{PV panel sizing}

For PV panel sizing, solar power rating needs to be calculated as shown in Eq. 3 [12]. After that, the number of PV panels for the system is calculated as in Eq. 4 [12].

$$
P_{P V}=\frac{E_{t} \times k_{1}}{P S H} \quad \text { Eq. } 3
$$

where $P_{P V}$ is the solar power rating in watt for PV panel in $W, k_{1}$ is the safety factor considering losses and $P S H$ is the peak sun hours. 


$$
N_{P V}=\text { round-up }\left(\frac{P_{P V}}{P_{P V_{\max }}}\right) \quad \text { Eq. } 4
$$

where $N_{P V}$ is the number of PV panel and $P_{P V_{\max }}$ is the maximum power of the PV panel.

\subsubsection{Inverter sizing}

The inverter is expected to convert $12 \mathrm{~V}$ DC from the solar panel to $230 \mathrm{~V} \mathrm{AC}$, for AC loads supply. To calculate the size of the inverter, the step in Eq. 5 should be followed, by including the percentage of energy losses in the system [13].

$$
P_{i n v}=P_{t} \times k_{2} \quad \text { Eq. } 5
$$

where $P_{i n v}$ is the power rating for inverter in $W, P_{t}$ is the total power rating of AC loads and $k_{2}$ is the safety factor considering losses.

\subsubsection{Charge controller sizing}

Same with inverter, charge controller sizing also needs to include the percentage of energy losses in the system in addition to short circuit current, $I_{s c}$. Therefore, the calculation for charge controller sizing is expected to be the same as in Eq. 6 [13].

$$
I_{c c}=\left(N_{P V} \times I_{s c} \times k_{3}\right) \quad \text { Eq. } 6
$$

where $I_{c c}$ is the current rating for charge controller in $A, I_{s c}$ is the short circuit current of PV panel and $k_{3}$ is the safety factor considering losses.

\subsection{Development of solar-powered automatic fertilizer system}

The development of a solar-powered automatic fertilizer system is executed in Arduino software with a proper algorithm. Prior to the execution of the automatic fertilizer code program, an overall configuration of the system is made according to Figure 3 . The overall block diagram in Figure 3 can be divided into three (3) main parts which are input, process and output.

- Input

A stand-alone PV system that consists of $10 \mathrm{~W}$ of poly-crystalline PV solar panel, charge controller, battery and inverter is used as the power supply for the loads through $12 \mathrm{~V}$ DC adapter. PV solar panel that made up of PV cells is charged by the sunlight and produces electrical energy in the form of DC. The charge controller will regulate the energy flowing from the PV panel to the battery bank. The DC supply will then be converted to the AC with the help of an inverter before transmitting the power to $12 \mathrm{~V}$ loads such as water pump and motor agitator.

- Process

From the charge controller, an output of 5V supply via USB cable is connected to the Arduino UNO board to power up the board. The input from the loads is being processed in Arduino UNO with several $\mathrm{C}++$ codes. From the sketches of the $\mathrm{C}++$ program code, the loads are expected to perform tasks according to the command e.g. water pumps will be pumping the solution of fertilizer A, fertilizer B and water into the mixer tank with appropriate algorithms.

- Output

OLED Display is used as the output indicator to represent the flow rate reading, distance reading and EC value from flow rate sensors, ultrasonic sensors and EC sensors, accordingly. The water cycle from the system is driven by the energy from the solar system with the aid of relays and water pumps. 


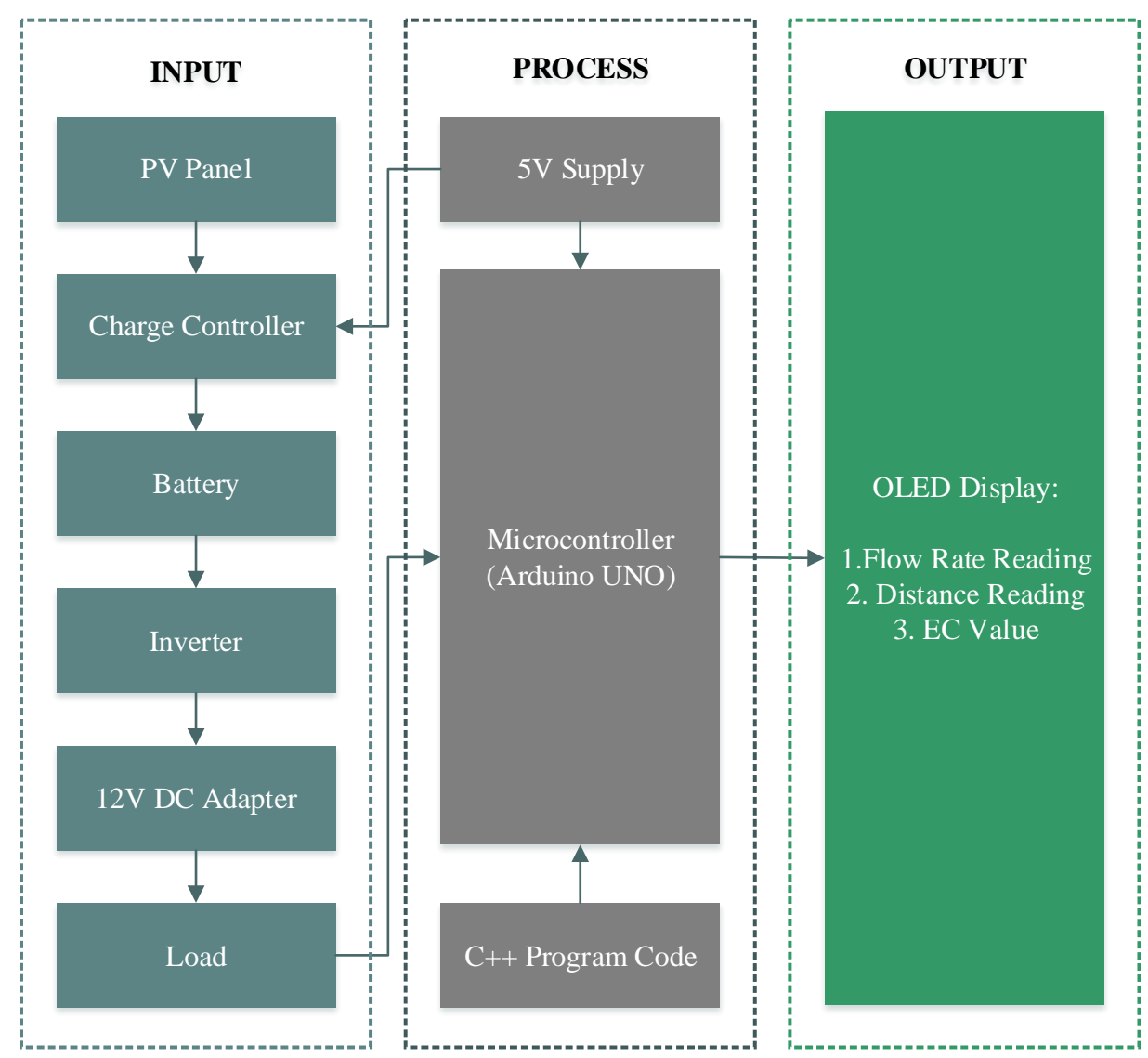

Figure 3: Overall block diagram of solar-powered automatic fertilizer system

Agitation of the inputs into the mixer tank is controlled by the algorithm that has been developed in Arduino IDE. The stocks of fertilizer A, fertilizer B and water are placed in three (3) separate tanks whilst another tank is used for the mixing process of the inputs. The process starts with the inputs of fertilizer A, fertilizer B and water. All these inputs will start flowing into the mixer tank once the relay is in the normally-closed (NC) condition, hence triggered the water pump to operate. To be specific, water pump 1 and water pump 2 which connected to flow rate sensor 1 and flow rate sensor 2 will independently stop operating once the amount of fertilizer A and fertilizer B reach $25 \mathrm{ml}$. While for water pump 3, it will stop pumping the water into the mixer tank when the ultrasonic sensor detects the water level in the tank is $17 \mathrm{~cm}$ away from the tank cover, which is equal to $2000 \mathrm{ml}$ of water solution. These values have met the required ratio for one (1) week-old chili plant i.e. $25 \mathrm{ml}$ of fertilizer A: $25 \mathrm{ml}$ fertilizer B: $2000 \mathrm{ml}$ water.

The operation of the motor agitator is also controlled by the ultrasonic sensor. Same with water pump 3, the motor agitator will start mixing the solution into the mixer tank when the water level is more than $16 \mathrm{~cm}$ from the tank cover in order to get a constant reading of EC value. Once the solution reaches $16 \mathrm{~cm}$, the mixing process stops. The speed of the motor can be regulated with the aid of potentiometer and L298N bridge. Then, the EC sensor reads the EC value and displays it on the OLED Display. Feedback mechanism for the EC sensor is instigated here to increase the accuracy of fertilizer intake, thus reducing the possibility of improper fertilizer usage. Apart from that, OLED Display is also used to display the distance for ultrasonic sensor and flow rate reading from the flow rate sensor. The overall mixing process of the system with its EC feedback mechanism can be simplified in Figure 4. 


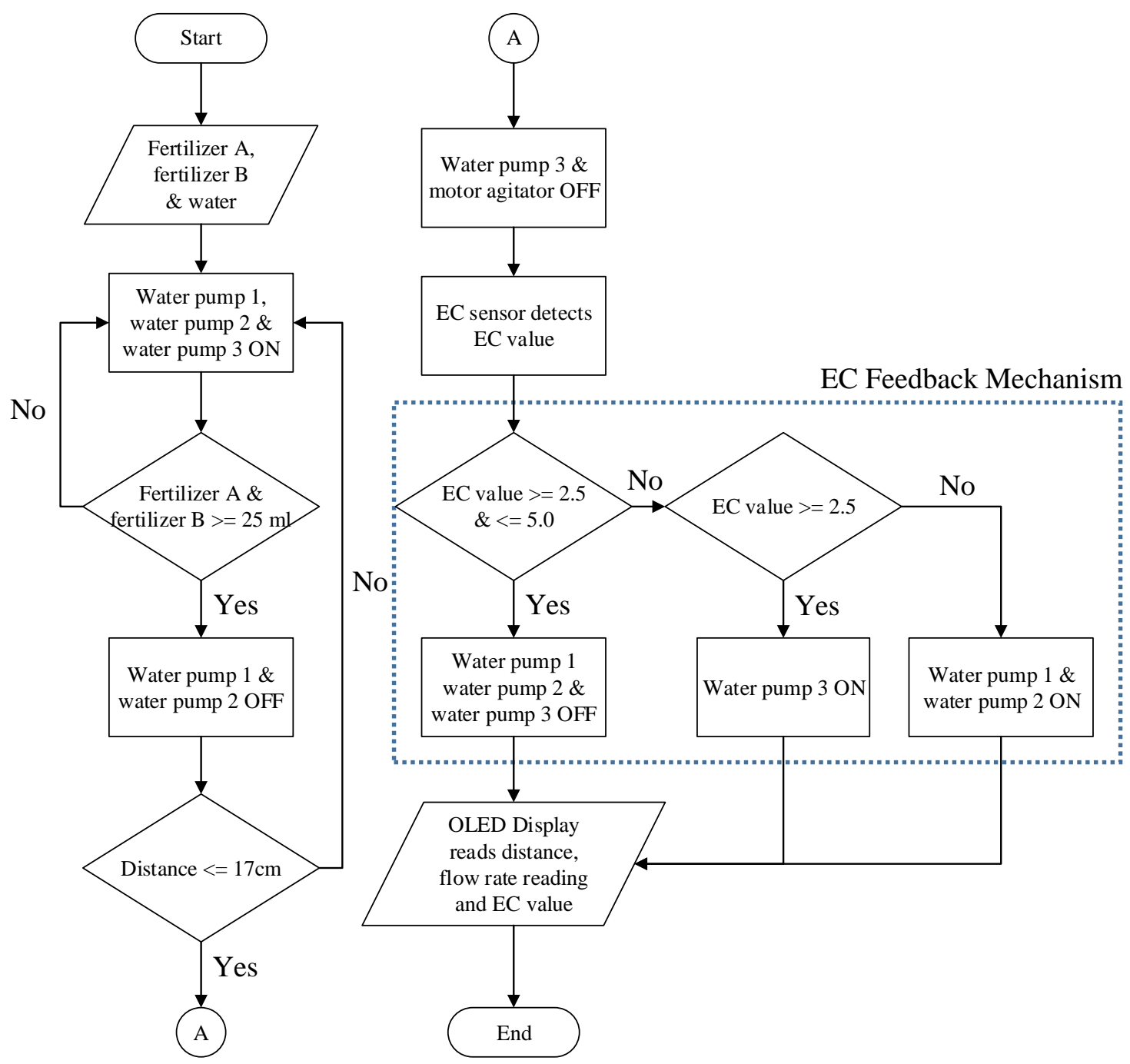

Figure 4: Flowchart for the fertilizer mixing system

\section{Results and Discussion}

This section is organized based on the result and analysis from the conducted methodologies from subtopic 2.1 and 2.2 , respectively.

\subsection{PV Sizing for Solar PV Design}

The calculation of PV solar system is based on 300 chili crops by considering several assumptions as in Table 1 [14]. The load estimation is referring to Table 2 and the results obtained is tabulated in Table 3. A block diagram that summarizes the overall sizing for the PV system for automatic fertilizer system is presented in Figure 5.

Table 1: Assumptions in a PV sizing system

\begin{tabular}{cc}
\hline Attribute & Value \\
\hline Peak sunshine hours $(P S H)$ & 4 hours \\
Autonomous days $(A D)$ & 3 days \\
Battery voltage $\left(V_{d c}\right)$ & $48 \mathrm{~V}$ \\
Allowable battery depth of discharge $(D O D)$ & 0.6 \\
The total efficiency of cable, battery, charge controller and inverter $(\eta)$ & 0.8 \\
Safety factor considering losses $\left(k_{1}, k_{2}\right.$ and $\left.k_{3}\right)$ & 1.3 \\
\hline
\end{tabular}


Table 2: Load estimation

\begin{tabular}{cccccc}
\hline Load & $\begin{array}{c}\text { Quantity, } \\
N\end{array}$ & $\begin{array}{c}\text { Power Rating, } \\
P(\mathrm{~kW})\end{array}$ & $\begin{array}{c}\text { Total Power, } \\
P(\mathrm{~kW})\end{array}$ & $\begin{array}{c}\text { Usage Hours } \\
\text { per Day, } h(\mathrm{~h})\end{array}$ & $\begin{array}{c}\text { Energy Demands, } \\
E_{\text {load }_{i}}(\mathrm{Wh})\end{array}$ \\
\hline \hline Motor pump & 2 & 0.37 & 0.74 & 0.38 & 281.2 \\
Motor agitator & 1 & 0.75 & 0.75 & 0.35 & 187.5 \\
\hline
\end{tabular}

Table 3: Component sizing

\begin{tabular}{ccc}
\hline Item & Size Needed & Size Selected \\
\hline Battery bank & $61.03 \mathrm{Ah}$ & $100 \mathrm{Ah}$ \\
PV panel & $152.33 \mathrm{~W}$ & $160 \mathrm{~W}$ \\
No. of PV panel & 0.95 & 1 \\
Inverter & $1.94 \mathrm{~kW}$ & $2 \mathrm{~kW}$ \\
Charge controller & $11.31 \mathrm{~A}$ & $15 \mathrm{~A}$ \\
\hline
\end{tabular}

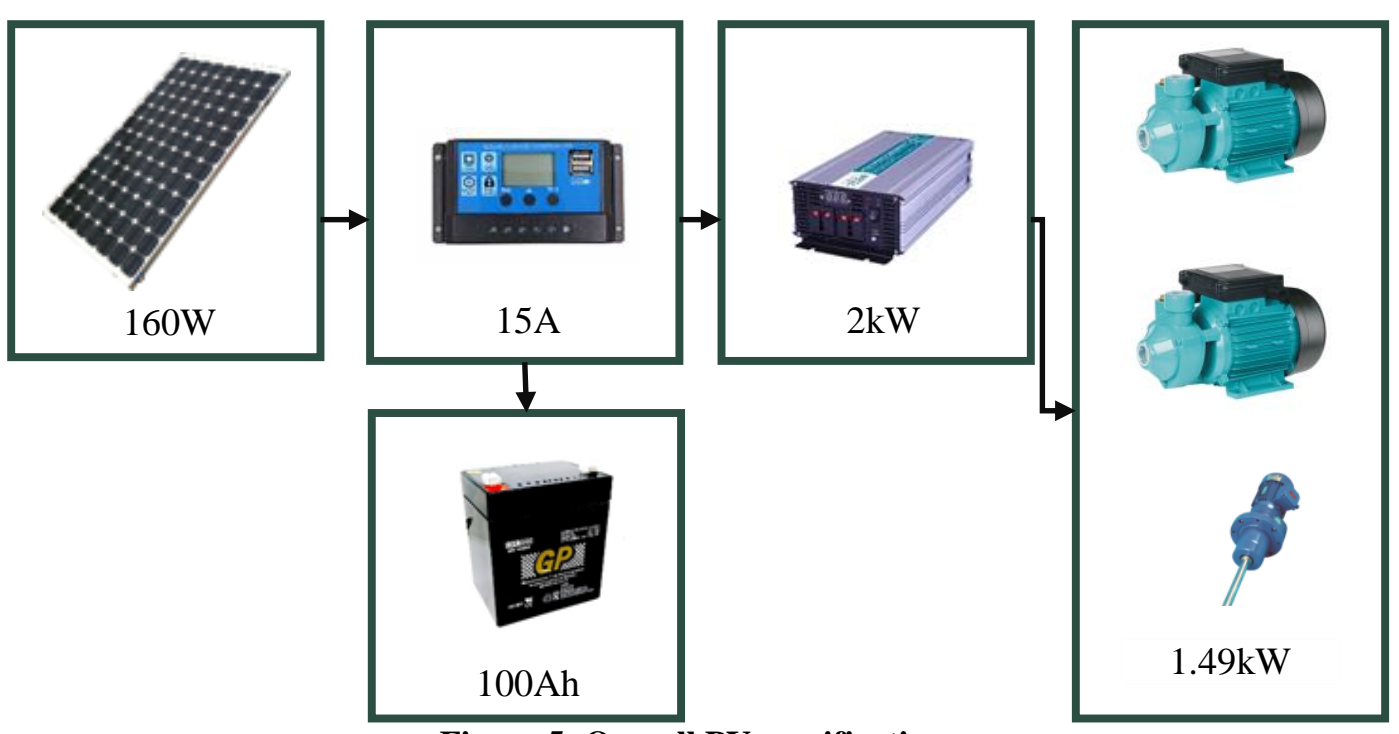

Figure 5: Overall PV specifications

Based on the result, it can be concluded the rated $48 \mathrm{~V}$ with $100 \mathrm{Ah}$ battery is enough to supply electricity for three (3) autonomy days to the motor pumps and motor mixer. By considering the cost product, it is best to select a 48V battery to satisfy the required Ah of the battery. Only one (1) $160 \mathrm{~W}$ panel is selected for this fertigation system. To meet the demand of $2 \mathrm{~kW}$ of the inverter, the farmers can either choose to buy a single inverter with the rated power of $2 \mathrm{~kW}$ or they can purchase two (2) $1 \mathrm{~kW}$ inverters. Sometimes, doubling the price of the low rated inverter is much cheaper than paying for only one (1) high rated inverter. 15A charge controller is used for the proposed system by choosing the short-circuit, $I_{S C}$ of $8.56 \mathrm{~A}$ for $160 \mathrm{~W}$ polycrystalline PV panel.

\subsection{Development of solar-powered automatic fertilizer system}

Circuit implementation for automatic fertilizer system and solar system are separately configurated in Fritzing software prior to the hardware development. Figure 6 and Figure 7 show the circuit design of automatic fertilizer system and solar system, accordingly. The water pump in Figure 6 is replaced with a motor pump icon due to the non-existing water pump Fritzing library.12V DC supply is fed into the inverter to get the supply from solar energy while the EC sensor is connected to the EC probe that is supposed to be dipped in the mixer tank, which is not shown in Figure 6. 


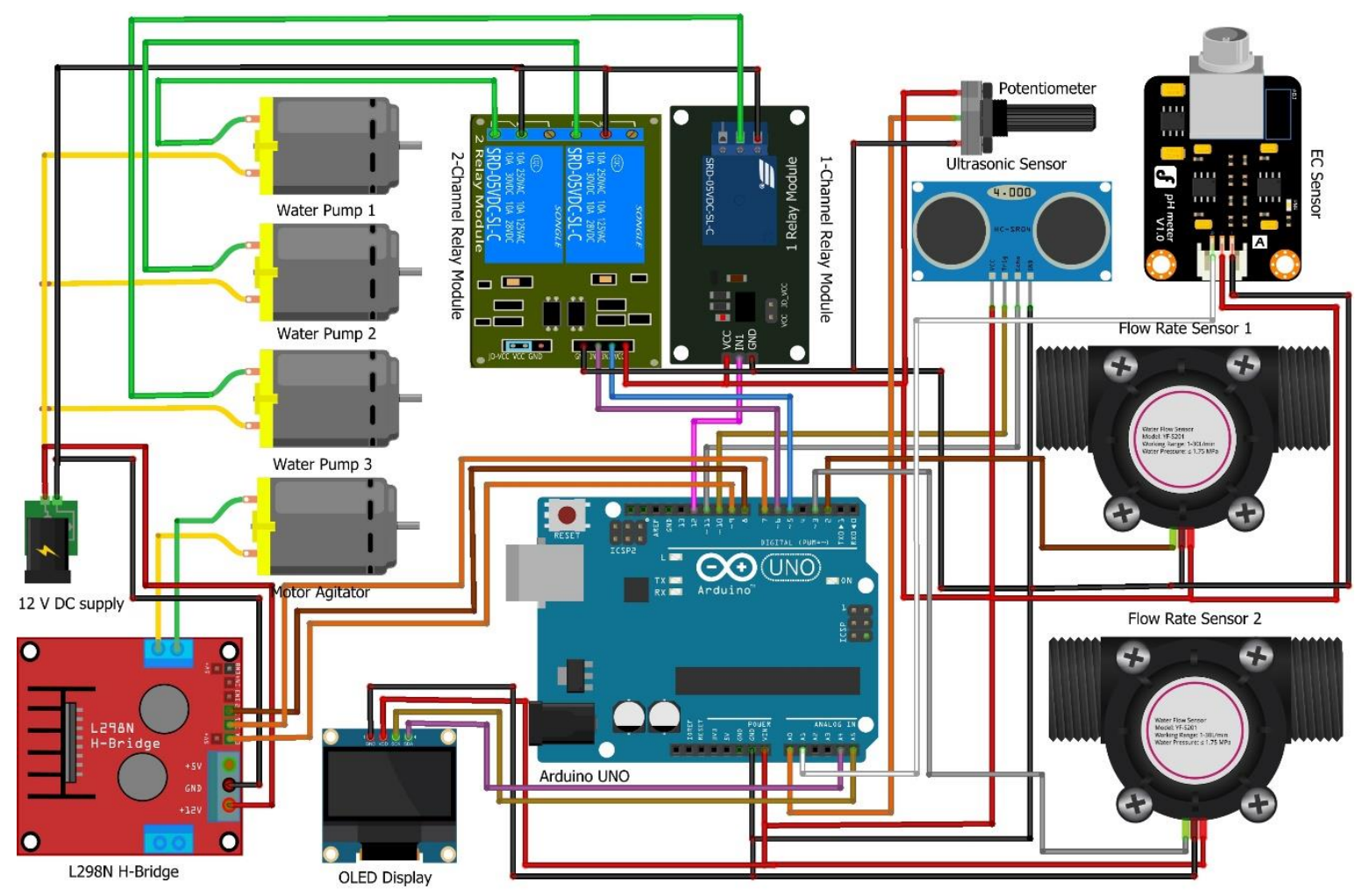

Figure 6: Automatic fertilizer circuit design

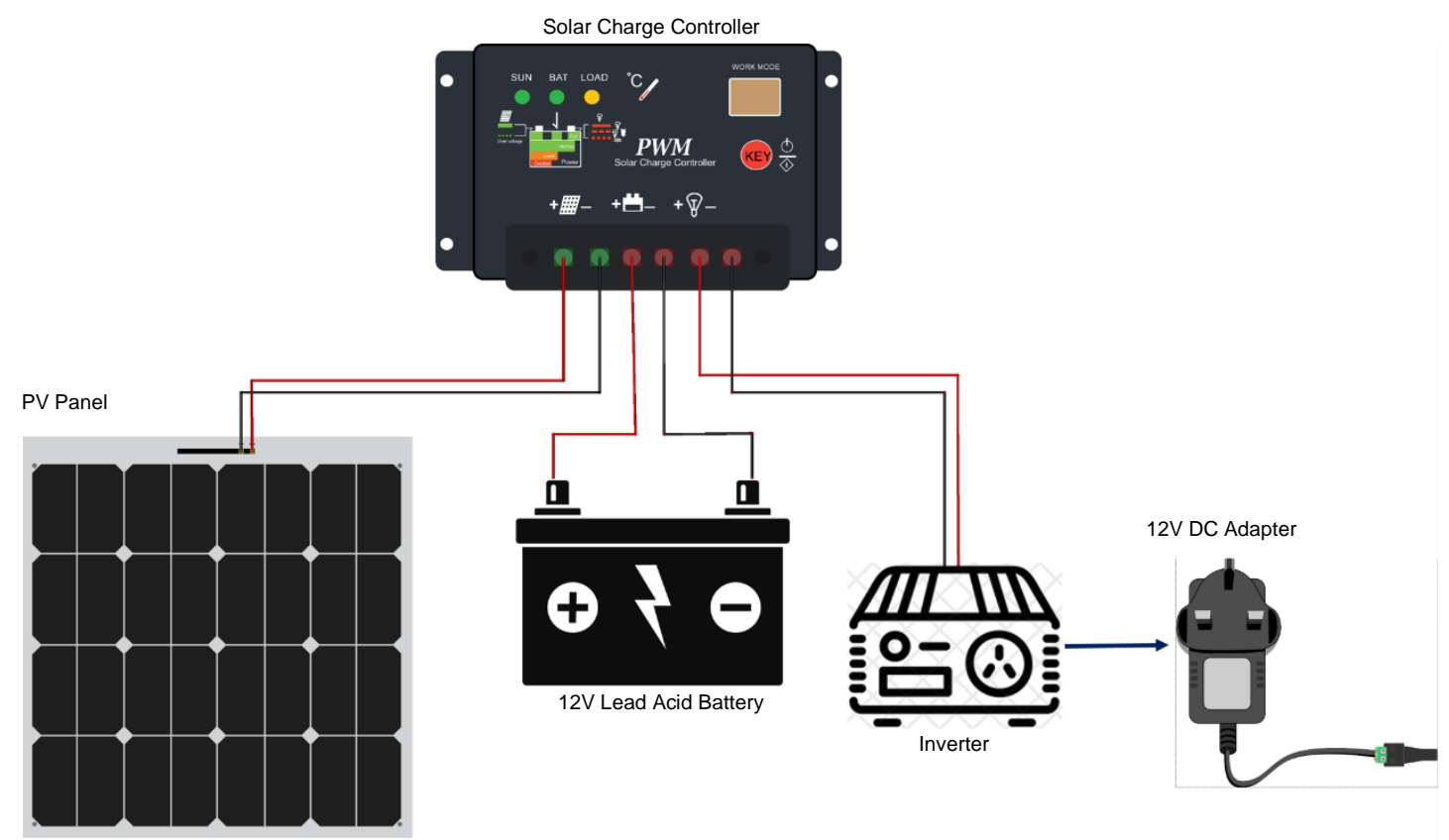

Figure 7:Circuit configuration for solar system

A test is conducted to test the performance of the proposed system and the final prototype of solarpowered automatic fertilizer system is implemented as in Figure 8. The prototype consists of three (3) tanks with respect to fertilizer A, fertilizer B and water and a tank for the mixing process. The circuit is placed neatly in a control box with OLED Display and potentiometer. The speed of the mixer can be regulated by the potentiometer. The $12 \mathrm{~V}$ loads such as water pump and motor agitator are getting supply from $12 \mathrm{~V} 4.5 \mathrm{Ah}$ battery bank via the inverter while the other sensors that work on $5 \mathrm{~V}$ are connected to USB cable before attached with the solar charge controller. 


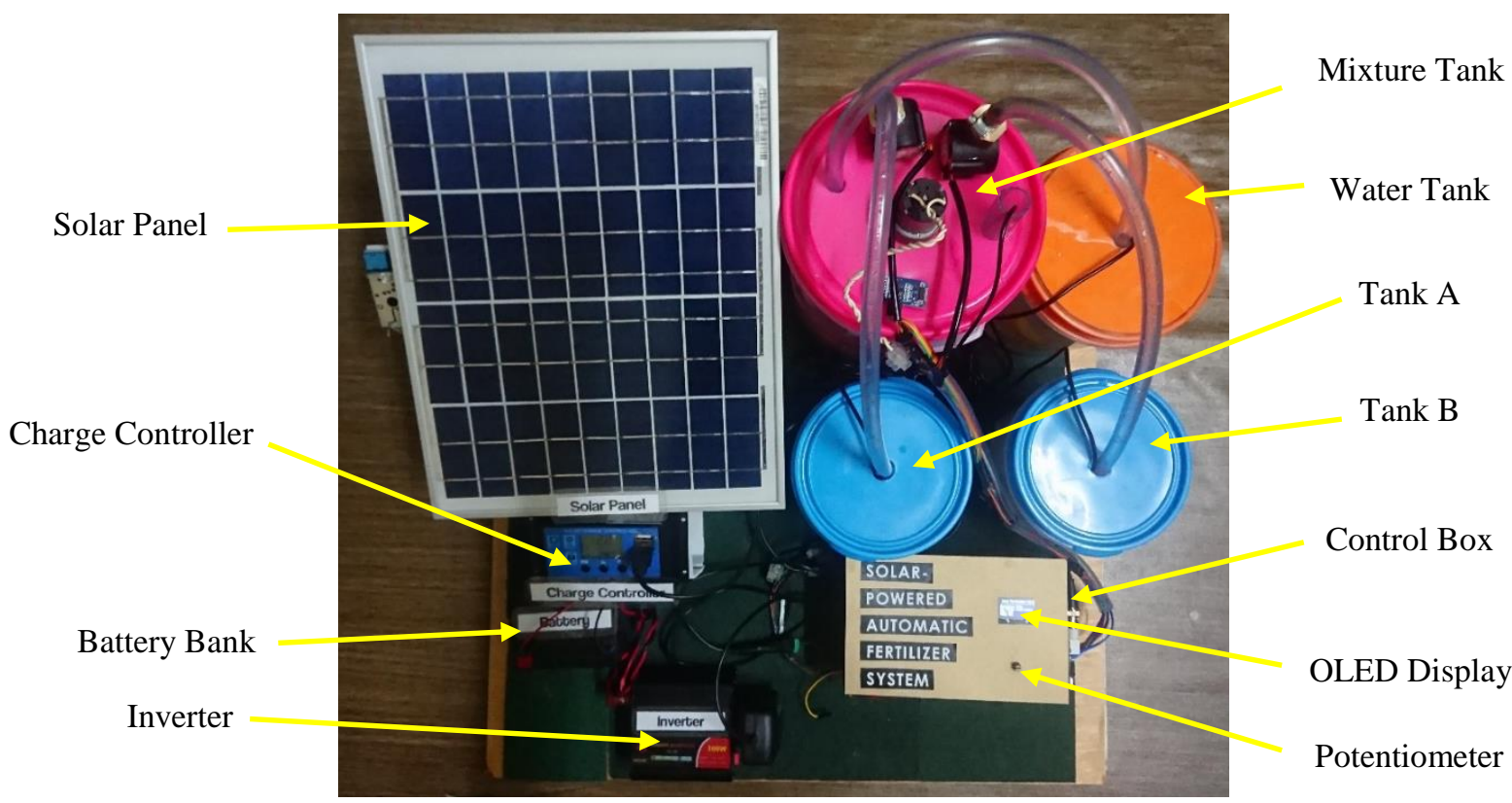

Figure 8: Final prototype of automatic fertilizer system

EC feedback mechanism has been executed with the immersion of EC sensor into two (2) different EC concentration; Condition 1 and Condition 2 . The overall performance of the automatic fertilizer system is tabulated in Table 4. The system is able to run accordingly with a little error appeared on flow rate sensor. Hence, the system can be implemented in the real automatic fertilizer system to ease the workload of the farmers.

Table 4: Overall performance of automatic fertilizer system

\begin{tabular}{|c|c|c|c|c|}
\hline Condition & & $\mathrm{D}$ & & Mechanism Involved \\
\hline \multirow{4}{*}{ Initial condition } & Distance & : & $23 \mathrm{~cm}$ & Water pump 3 activated \\
\hline & FR 1 & : & $0 \mathrm{ml}$ & Water pump 1 activated \\
\hline & FR 2 & : & $0 \mathrm{ml}$ & Water pump 2 activated \\
\hline & EC value & : & $0.00 \mathrm{mS} / \mathrm{cm}$ & - \\
\hline \multirow{5}{*}{ Final Condition } & Distance & : & $17 \mathrm{~cm}$ & $\begin{array}{l}\text { Water pump } 3 \text { stop pumping } \\
\text { water at } 17 \mathrm{~cm}\end{array}$ \\
\hline & FR 1 & : & $67 \mathrm{ml}$ & $\begin{array}{l}\text { Water pump } 1 \text { stop pumping } \\
\text { fertilizer A when FR } 1 \text { detect } \\
\text { flowing solution is more than }\end{array}$ \\
\hline & & & & $25 \mathrm{ml}$ \\
\hline & FR 2 & : & $95 \mathrm{ml}$ & $\begin{array}{l}\text { Water pump } 2 \text { stop pumping } \\
\text { fertilizer A when FR } 2 \text { detect } \\
\text { flowing solution is more than } \\
\qquad 25 \mathrm{ml}\end{array}$ \\
\hline & EC value & $:$ & $4.11 \mathrm{mS} / \mathrm{cm}$ & - \\
\hline \multirow{4}{*}{ Condition 1} & Distance & : & - & Water pump 3 activated \\
\hline & FR 1 & : & - & Water pump 1 off \\
\hline & FR 2 & : & - & Water pump 2 off \\
\hline & EC value & : & $5.83 \mathrm{mS} / \mathrm{cm}$ & - \\
\hline \multirow{4}{*}{ Condition 2} & Distance & : & - & Water pump 3 off \\
\hline & FR 1 & : & - & Water pump 1 on \\
\hline & FR 2 & : & - & Water pump 2 on \\
\hline & EC value & $:$ & $0.45 \mathrm{mS} / \mathrm{cm}$ & - \\
\hline
\end{tabular}




\section{Conclusion}

In conclusion, all objectives of this project were successfully achieved. The main objective is to design a PV system for the automatic fertilizer system in chili fertigation technology. PV solar sizing for each component such as the PV panel, solar charge controller, inverter and battery were properly calculated by considering the load requirement. The second objective is also able to be fulfilled by sketching the algorithm of the automatic fertilizer system in Arduino IDE software. The system is designed to automatically agitate the precise proportion of the fertilizer. In order to do so, the ratio of fertilizer A, fertilizer B and water is introduced. The last objective is to develop a prototype from the developed algorithm and then integrate it with the solar system. This system had successfully implemented and the output parameters which are distance, flow rate reading and EC value had been properly displayed via OLED Display. The solar system is also able to supply adequate electricity to the loads. conclusion should summarize the main findings of the study, and restate the key points inferred from trends observed and discussed regarding the data. Some suggestions should be included to encourage the continuation of the current research.

With regards to some limitations of the project, several improvements need to be considered for the future works of the automatic fertilizer system as per listed below:

- Develop a fully automatic fertilizer system that considers the parameters such as sand moisture, sand $\mathrm{pH}$, humidity and surrounding temperature. Such parameters are also as crucial as EC value and the dosage of fertilizer. Implementing humidity, moisture, $\mathrm{pH}$ and temperature sensors into the system is good enough to enhance the accuracy and efficiency of the system;

- Implement a solar monitoring system in order to get a continuous power supply for the fertigation. By doing so, the farmers are able to detect any unwanted particles such as dirt, dust or shading that can affect the solar performance in supplying a prolong electricity;

- Design a GUI for the automatic fertilizer system where the users are able to choose the required $\mathrm{EC}$ value in line with the age of the plant. The visible icons in GUI will make it easier for the farmers to carry out the tasks which are related to the fertigation system;

- Use a high-quality sensor in order to enhance the performance of the system. The different sensor has a different range of sensitivity and accuracy. Therefore, the specification of the sensor needs to be taken into account to ensure the compatibility of the sensor when integrating with the MCU so that the programmed code can be executed appropriately to the hardware system; and

- It is advisable to add on another $12 \mathrm{~V} 4.5 \mathrm{Ah}$ battery bank to the solar system to increase the storage of the supply. Battery banks should be placed in parallel order to get a high value of current. By doing so, the solar system is expected to provide electricity in a much longer period.

\section{Acknowledgement}

This research was made possible by funding from research grant number E-DANA MESTECC (K248). The authors would also like to thank the Faculty of Electrical and Electronic Engineering, Universiti Tun Hussein Onn Malaysia for its support.

\section{References}

[1] "Department of Statistics Malaysia Official Portal." [Online]. Available: https://www.dosm.gov.my/v1/index.php?r=column/cthemeByCat\&cat=72\&bul_id=UjYxeDN kZ0xOUjhFeHpna20wUUJOUT09\&menu_id=Z0VTZGU1UHBUT1VJMFlpaXRRR0xpdz09. [Accessed: 21 Sep 2019]

[2] “Adoption of Technology in Malaysia's Livestock Industry." [Online]. Available: http://ap.fftc.agnet.org/ap_db.php?id=946. [Accessed: 30 Sep 2019]

[3] I. B. No, Soil and Water Management Innovations towards Doubling the Farmers ' Income, no. 32. 2018 
[4] J. Ruan, P. Liao, and C. Dong, "The design and research on intelligent fertigation system," Proc. - 2015 7th Int. Conf. Intell. Human-Machine Syst. Cybern. IHMSC 2015, vol. 2, pp. 456-459, 2015

[5] Dr. Ahmad Safuan Bujang, "Sustainable Food Production Through Fertigation System - Blog Rasmi MARDI," Institut Kemajuan dan Penyelidikan Pertanian Malaysia, 2017. [Online]. Available: https://blogmardi.wordpress.com/2017/02/02/sustainable-food-production-throughfertigation-system/. [Accessed: 25 Sep 2019]

[6] Z. Wiesman and Z. Wiesman, "Biotechnologies for intensive production of olives in desert conditions," Desert Olive Oil Cultiv., pp. 87-133, Jan. 2009

[7] K. Saroch, S. K. Sandal, and N. Datt, "Studies on effect of irrigation interval and fertigation frequency on crop growth, water use and productivity of summer brinjal," vol. 42, no. 1, pp. 12-16, 2016

[8] M. H. Alsharif, R. Nordin, and M. Ismail, "Green wireless network optimisation strategies within smart grid environments for Long Term Evolution (LTE) cellular networks in Malaysia," Renew. Energy, vol. 85, no. 2016, pp. 157-170, 2016

[9] W. S. W. Abdullah, M. Osman, M. Z. A. A. Kadir, and R. Verayiah, "The potential and status of renewable energy development in Malaysia," Energies, vol. 12, no. 12, 2019

[10] L. A. Nguimdo and L. T. Tassi, "Optimum Sizing and Economic Analysis of Standalone PV System with a Small Size Grinding Mill,” pp. 432-444, 2020

[11] Malaysia Energy Policy, Laws and Regulations Handbook Volume 1 Strategic ... - IBP, Inc. Google Books. Washington, DC 20003: International Business Publications, USA, 2015

[12] A. B. Guzmán, R. B. Vicencio, J. A. Ardila-Rey, E. N. Ahumada, A. G. Araya, and G. A. Moreno, "A cost-effective methodology for sizing solar pv systems for existing irrigation facilities in chile," Energies, vol. 11, no. 7, 2018

[13] A. Chai, N. Lung, and I. Journal, "International Journal of Advanced Trends in Computer Science and Engineering". [Online] Available: http://www.warse.org/IJATCSE/static/pdf/file/ijatcse2691.22020.pdf "Development of User Interface Design Tool and Training Kit for Standalone,” vol. 9, pp. 174-180, 2020

[14] T. Kulworawanichpong and J. J. Mwambeleko, "Design and costing of a stand-alone solar photovoltaic system for a Tanzanian rural household," Sustain. Energy Technol. Assessments, vol. 12, pp. 53-59, 2015 